\title{
Timing and mechanisms of North Atlantic Cenozoic uplift: evidence for mantle upwelling
}

\author{
MAX ROHRMAN ${ }^{1,2}$, PETER A. VAN DER BEEK ${ }^{3}$, \\ ROB D. VAN DER HILST ${ }^{4} \&$ PAUL REEMST $^{5}$ \\ ${ }^{1}$ Landmark Graphics, Stavanger, Norway \\ ${ }^{2}$ Present address: Shell UK Exploration \& Production, 1 Altens Farm Rd, \\ Nigg, Aberdeen ABI2 3FY, UK \\ (e-mail: max.rohrman@expro.shell.co.uk) \\ ${ }^{3}$ Laboratoire de Géodynamique des Chaînes Alpines, Université Joseph Fourier, \\ Grenoble, France \\ ${ }^{4}$ Department of Earth, Atmospheric and Planetary Sciences, MIT, Cambridge, MA 02139, USA \\ ${ }^{5}$ Geologica AS, Stavanger, Norway (present address: NAM, Assen, The Netherlands)
}

\begin{abstract}
Postrift domal uplift patterns are a distinct feature of northern North Atlantic margins. On the basis of apatite fission-track data, offshore seismic stratigraphy, geomorphology, gravity and seismic tomography, we argue that southern Norway is characterized by predominantly Neogene domal uplift. The uplift is tectonically driven and estimated at around $1.5 \mathrm{~km}$. Low flexural rigidity $\left(c .10^{22} \mathrm{~N} \mathrm{~m}\right)$ and corresponding equivalent elastic thickness $T_{\mathrm{e}}(c .15 \mathrm{~km})$ values for the southern Norwegian lithosphere indicate that the lithosphere is relatively weak. Additionally, high temperature estimates derived from low-velocity mantle P-and S-wave seismic tomography below the dome suggest a thermal anomaly at depth. Therefore, the observed topography is most plausibly explained by mantle upwelling. This would supercede other previously proposed primary mechanisms such as eustasy, isostatic readjustment to glacial erosion, magmatic underplating and intraplate compression. Currently available data suggest similar processes for other uplifted regions such as Spitsbergen, northern Norway, the British Isles and parts of East Greenland.
\end{abstract}

During recent decades it has become apparent that the North Atlantic margins experienced substantial vertical movements in Cenozoic time (e.g. White \& Lovell 1997; Doré et al. 1999; Japsen \& Chalmers 2000) characterized by the coupled emergence of rift margins and anomalous subsidence of the nearby basins (e.g. Cloetingh et al. 1990). However, the mechanism as well as its temporal and spatial resolution has been a matter of debate. Recently, some progress has been made with respect to timing, and two phases that have influenced the whole North Atlantic region have been identified (e.g. Riis 1996; Martinsen et al. 1999). The first is a Paleogene phase primarily associated with Eocene rifting and contemporaneous volcanism generated by the Iceland mantle plume (e.g. Doré et al. 1999). There is considerable evidence that this event affected all regions around the North Atlantic (Britain, Norway and Greenland), although its magnitude differed from region to region (e.g. Green et al. 1993; Riis 1996; Dam et al. 1998; Doré et al. 1999). The second is a
Neogene phase (Rohrman \& van der Beek 1996; Japsen \& Chalmers 2000), which has a more enigmatic cause. This event is characterized by substantial uplift of Britain, parts of Norway, Spitsbergen, the Faeroes and Greenland (Japsen \& Chalmers 2000) and by associated subsidence of nearby basins (e.g. North Sea, Møre Basin, offshore Greenland, Sørvestnaget Basin, Rockall Trough, Porcupine Basin). Because of the association of uplift and subsidence, the mechanism driving these processes is probably tectonic (e.g. Doré et al. 1999; Japsen \& Chalmers 2000). Various mechanisms have been proposed including intraplate compression (Cloetingh et al. 1990; Doré et al. 1999), mantle phase changes (Riis \& Fjeldskaar 1992), magmatic underplating (Cox 1993; Brodie \& White 1995) and small-scale asthenospheric convection (Vågnes \& Amundsen 1993; Rohrman \& van der Beek 1996; Stuevold \& Eldholm 1996), among others.

In this paper, we briefly review proposed mechanisms for uplift around the North Atlantic. 
Subsequently, we focus on southern Norway, and review the evidence for the timing and magnitude of Neogene uplift and denudation. We calculate tectonic uplift from the elevation of plateausurface remnants and an estimate of flexural rigidity from the coherence between Bouguer gravity and topography. These results are then used to differentiate between mechanisms proposed. Additionally, we present seismic tomographic images of $\mathrm{P}$-wave velocities in the upper mantle around the North Atlantic and correlate these with other data, to arrive at the most plausible mechanism operating during Neogene time.

\section{Mechanisms proposed}

Early studies were mainly focused on Norway and primarily based on geomorphological observations (e.g. Holtedahl 1953; Torske 1972). The rugged mountains of southern Norway, spectacular fjords and preservation of plateau surfaces at high altitude (Gjessing 1967; Peulvast 1985; Riis 1996) strongly suggest a recent upwarp of the southern Norwegian landmass. Intensive hydrocarbon exploration of offshore Norway has provided further evidence from observed structural basinward dip of preNeogene strata and build-up of large clastic wedges (Jordt et al. 1995). Palaeogeographical reconstructions have added additional evidence for a late emergence (Doré 1992a, 1992b). Apatite fission-track (AFT) data constrain denudation to be a mainly Neogene event, starting at c. $30 \mathrm{Ma}$. Denudation occurred in a dome-like pattern with the amplitude of denudation decreasing radially outward from a maximum of $2.0 \pm 0.5 \mathrm{~km}$ at the centre (Rohrman et al. 1995). The timing of the onset of denudation is consistent with offshore stratigraphic evidence (Rundberg \& Smalley 1989; Jordt et al. 1995).

Any mechanism proposed, to be successful, has to explain this timing of events (van der Beek \& Rohrman 1997). Some workers favour a Paleogene onset of uplift for southern Norway, but most available evidence strongly suggests a primarily Neogene event (Rundberg \& Smalley 1989; Jensen \& Schmidt 1993; Jordt et al. 1995; Rohrman et al. 1995; Riis 1996; Martinsen et al. 1999).

Early interpretations suggested that uplift of southern Norway and other margins around the North Atlantic was associated with PaleoceneEocene break-up and plume activity (e.g. Torske 1972; Cox 1993). However, timing of domal uplift at c. 30 Ma, i.e. 25-30 Ma after onset of Eocene volcanism and rifting, precludes significant synrift uplift. Moreover, dynamic plume-generated uplift is transient, and should reverse into subsidence after break-up. Permanent uplift can be generated by magmatic underplating, but in the case of southern Norway there is no sign of onshore Cenozoic intrusions. Eocene magmatic activity took place $300-$ $400 \mathrm{~km}$ offshore.

Riis \& Fjeldskaar (1992) proposed that most of the Norwegian uplift was caused by PliocenePleistocene isostatic readjustment to glacial erosion. However, their study showed that additional tectonic uplift is required to explain the present-day elevation of morphological surfaces. They explained this by mantle phase transitions as a result of erosional unloading, but the dynamics of mantle phase changes driving this tectonic uplift component are at present poorly understood. Non-tectonic mechanisms that have been suggested (Eyles 1996) focus on climatic deterioration and sea-level changes. However, the kilometre-scale magnitude of uplift is not readily explained by eustasy.

Others have proposed that Neogene uplift of western Fennoscandia is a result of thermal instability caused by large horizontal temperature gradients between the Fennoscandian mainland and the Norwegian-Greenland Sea (Theilen \& Meissner 1979; Peulvast 1985; Vågnes \& Amundsen 1993). This would set up secondary convection in the sub-lithospheric mantle, causing the hot asthenosphere to rise and subsequently generate tectonic uplift. This could be a viable model, and will be discussed in the following sections.

Finally, various workers have drawn attention to the synchronous timing of margin uplift and anomalous basin subsidence around Norway and the whole North Atlantic, suggesting that coupled uplift and subsidence is flexural in nature and induced by intraplate stress fluctuations (Cloetingh et al. 1990). However, flexureinduced uplift is not consistent with the observed correlation between topography and Bouguer gravity anomalies (up to $-80 \mathrm{mgal}$ ) below the uplifted regions (Fig. 1). Although the gravity is largely isostatically compensated (Balling 1980), there is a mass deficit below the regions of highest elevation that cannot be explained by topography and differences in crustal thickness.

\section{Timing of denudation on the eastern Atlantic margin}

There are two principal types of constraint on the timing of Norwegian denudation: the structural 


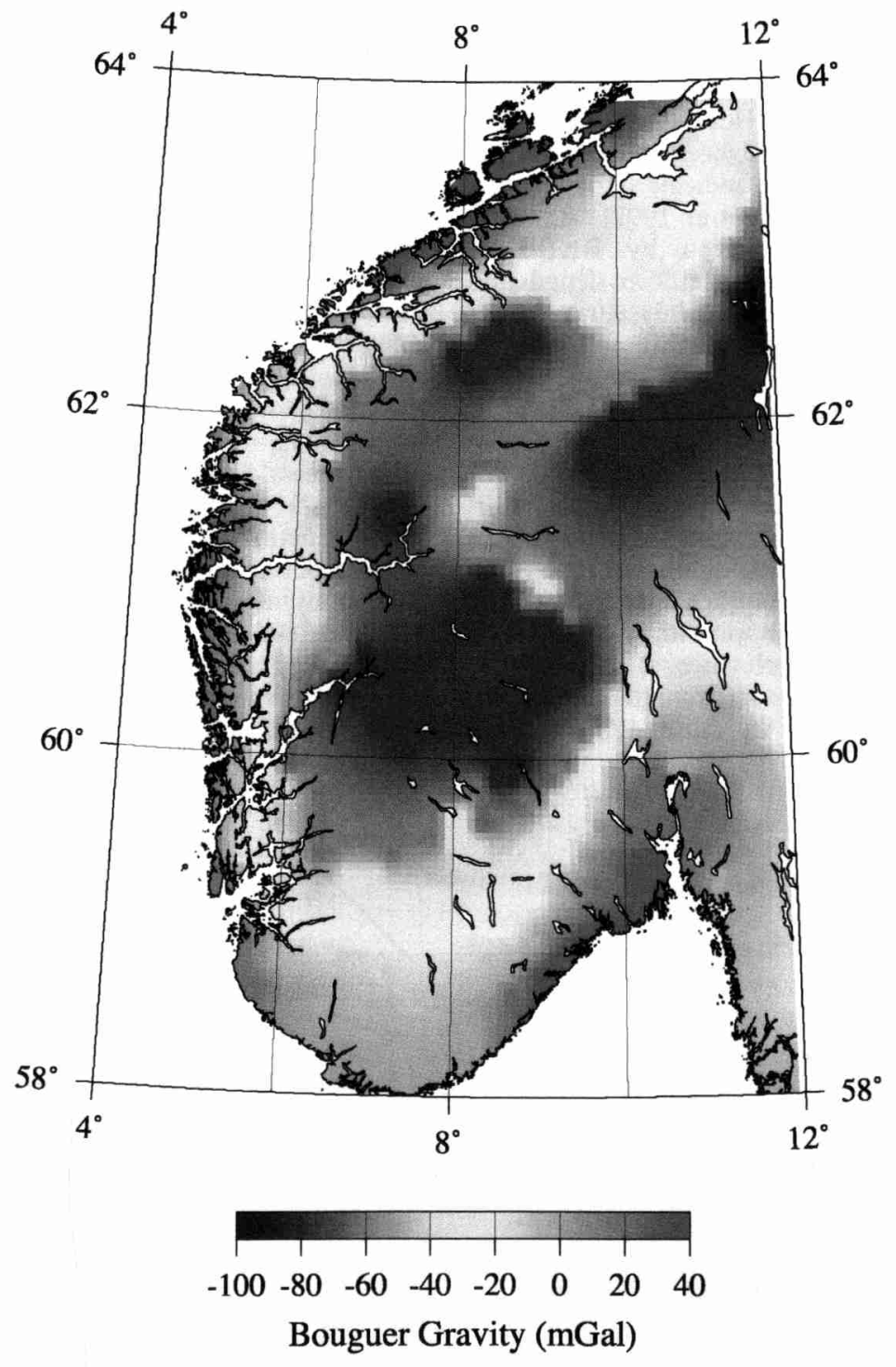

Fig. 1. Bouguer gravity anomaly map for southern Norway, data from Sveriges Geologiske Undersökelse (1985).

and stratigraphic relationship of Cenozoic strata offshore (Jordt et al. 1995) and planation surfaces onshore, and the AFT analysis of the Norwegian basement (Rohrman et al. 1995). AFT data from southern Norway define a structural dome with the youngest ages increasing radially from $c$. $100 \mathrm{Ma}$ at sea level in the inner fjords, to $c$. $170 \mathrm{Ma}$ at the top of the Jotunheimen peaks and around $200 \mathrm{Ma}$ at elevations less than $500 \mathrm{~m}$ near the shorelines (Fig. 2). Mean track length distributions are more variable, but the younger ages generally correspond to low mean track lengths (c. $11.6 \mu \mathrm{m})$ and a lack of long (recent) tracks (Fig. 2). The latter indicate fast cooling from temperatures at the lower end of the partial annealing zone $\left(c .60-70^{\circ} \mathrm{C}\right)$ to surface temperatures. Although our youngest AFT samples yield mixed ages, it is possible to extract thermal history information by using state-of-the-art modelling techniques. The youngest AFT samples (AFT age $c .100 \mathrm{Ma}$, mean track lengths $11.6 \mu \mathrm{m}$ ) suggest a predominantly Neogene onset of denudation (Rohrman et al. 1995). 
Northern Norway shows similar AFT basement ages although they tend to be somewhat older (around $160 \mathrm{Ma}$ ) with distributions showing longer track lengths (Hendriks \& Andriessen 2002). Meanwhile, Neogene clastic wedges offshore from Lofoten indicate more recent erosion (Mokhtari \& Pegrum 1992). A recent AFT study of Spitsbergen by Blythe \& Kleinspehn (1998) placed significant denudation around $36 \mathrm{Ma}$, which was mainly attributed by those workers to rift flank uplift, followed by Pliocene-Holocene glacial erosion. The data pattern yields strongly varying AFT ages (c. 27-56 Ma), sometimes within the same locality. This pattern suggests that the samples experienced other processes than simple uplift and erosion, possibly indicating migration of hot fluids. This interpretation is supported by the resetting of zircon fission-track ages and vitrinite reflection data, in the proximity of unreset samples at similar elevations. A possible explanation for these patterns might be volcanic and hydrothermal activity during Miocene and
Quaternary time (e.g. Vågnes \& Amundsen 1993). Similar fission-track patterns have been observed in the Permian Oslo Rift, where igneous activity is well documented (e.g. Rohrman et al. 1994). However, at sea level there seems to be a slight trend from west to east along the Longyearbyen fjord (Central Spitsbergen), which suggests a decrease in AFT ages from around 50 Ma near the basement on the west coast to $38 \mathrm{Ma}$ in the Eocene deltaic strata of the Central Basin. This concurs with earlier studies (Nøttvedt et al. 1992), suggesting Neogene domal uplift based on geological observations, vitrinite reflectance and seismic velocity data. Evidently, more AFT samples of east Spitsbergen are needed to verify or refute this assumption.

Much of the British Isles lacks the high rugged topography of southern Norway. Elevations are more subdued and do not exceed $1 \mathrm{~km}$ in large parts of England, Wales and Ireland. Only the Scottish highlands reach higher elevations, up to $1343 \mathrm{~m}$. Published AFT data from Scotland

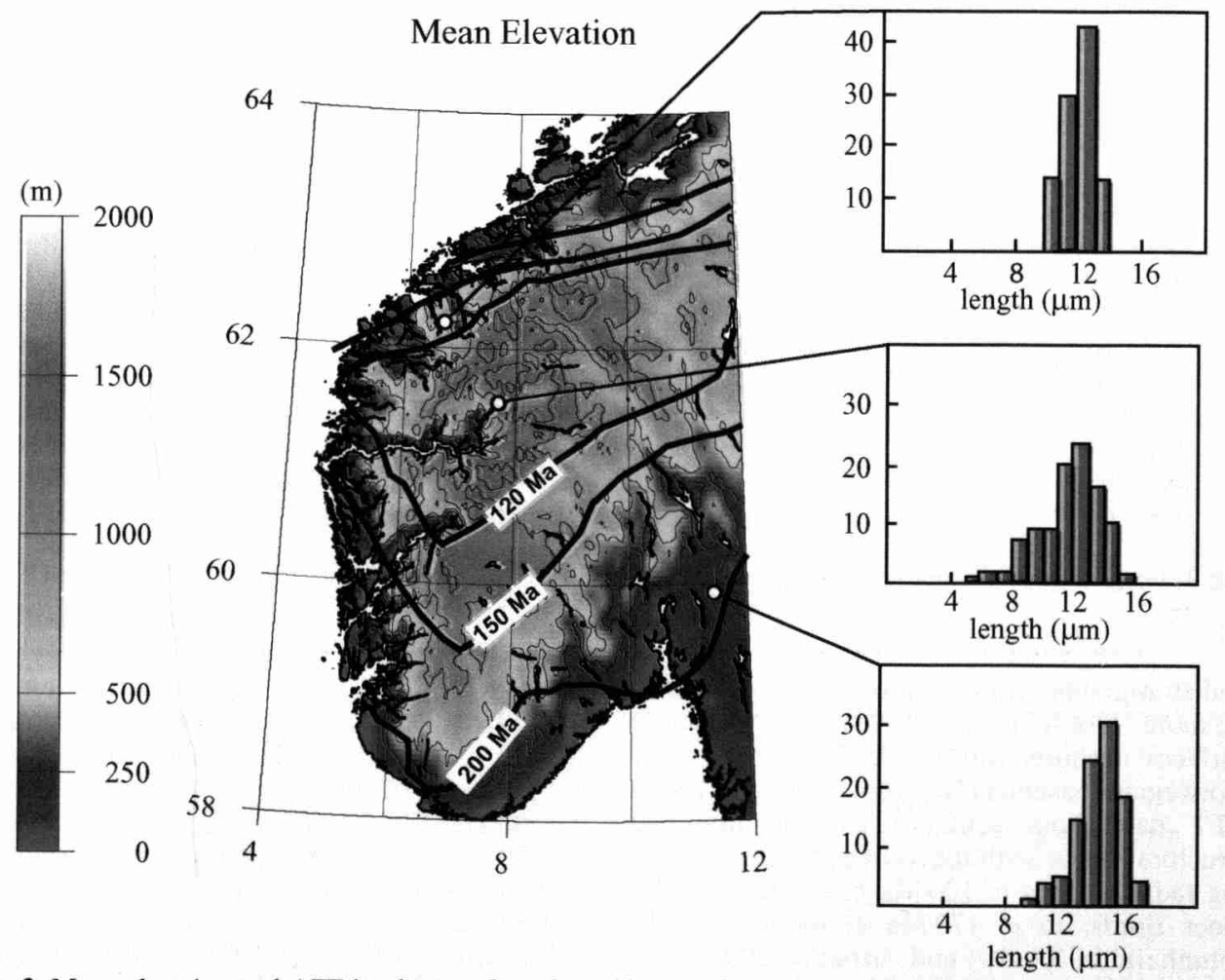

Fig. 2. Mean elevation and AFT isochrons of southern Norway drawn at sea level, defining a structural dome concordant with topography, from Rohrman et al. (1995). Typical track length distributions for selected samples are shown on the right. 
(Lewis et al. 1992) suggest predominantly Triassic-Jurassic ages. Only near the Eocene intrusions are younger ages found. However, data are too sparse to infer any details for this region. AFT data from northern England and the Irish Sea area show AFT ages between $45 \mathrm{Ma}$ and $>400 \mathrm{Ma}$ (Green et al. 1993, 1997, 2001), suggesting significant exhumation around $60 \mathrm{Ma}$. This uplift is possibly centred in the East Irish Sea and decreasing to the SE, concordant with the Mesozoic sedimentary outcrop pattern of southeastern England. Recently, Japsen (1997) suggested evidence for a Neogene denudation phase based on AFT data and compaction studies from eastern England and the western North Sea. He estimated that Paleogene and Neogene denudation were equal in magnitude (around $1 \mathrm{~km}$ each). However, the spatial pattern of both Neogene and Paleogene denudation for the entire United Kingdom requires further study.

Moreover, the area of highest denudation (East Irish Sea) is at present below sea level, in contrast to the dome-shaped topography of the other regions (southern Norway, northern Norway and Spitsbergen).

\section{Quantification of Neogene uplift and denudation in southern Norway}

Regional changes in surface elevation are the combined result of tectonic uplift, erosion and the isostatic response to erosion. To use the present-day elevation of an uplifted region to constrain tectonic processes, the components of elevation change that result from erosion and isostatic rebound must be quantified (England \& Molnar 1990; Gilchrist et al. 1994). The tectonic uplift $\left(u_{\mathrm{T}}\right)$ is related to the present-day elevation
$\left(H_{0}\right)$ and the amount of denudation $(\Delta E)$ by

$$
u_{\mathrm{T}}=H_{0}-H_{\mathrm{i}}+\Delta E-I
$$

where $H_{\mathrm{i}}$ is the initial elevation and $I$ is isostatic rebound:

$$
I=\left(\frac{\Delta E \rho_{\mathrm{c}}}{\rho_{\mathrm{a}}}\right)\left(1+\frac{D k_{\mathrm{E}}^{4}}{\left(\rho_{\mathrm{a}}-\rho_{\mathrm{c}}\right) \mathrm{g}}\right)^{-1}
$$

where $\rho_{\mathrm{c}}$ is the density of the eroded crustal section, $\rho_{\mathrm{a}}$ is sublithospheric mantle density, $k_{\mathrm{E}}$ is the spatial wavenumber of erosional unloading, $g$ is acceleration of gravity and $D$ is flexural rigidity (van der Beek et al. 1994; see Table 1). As $\mathrm{D} \rightarrow 0$, equation (2) simplifies to $I=\Delta E \rho_{\mathrm{c}} / \rho_{\mathrm{a}}$, the local isostatic solution. As $\mathrm{D} \rightarrow \infty$ (for an infinitely strong lithosphere), $I \rightarrow 0$. A regional analysis of tectonic uplift therefore requires an estimate of $H_{\mathrm{i}}$ and $D$, as well as the ability to map out spatial variations in $\Delta E$ (Abbott et al. 1997; Small \& Anderson 1998).

Whereas the AFT thermochronological data discussed above give us a high temporal resolution to decipher the denudation history of southern Norway, the spatial resolution of our data is rather coarse. We therefore use the elevation of preserved remnants of a plateau surface (the 'Palaeic surface') to spatially constrain the amounts of denudation, isostatic rebound, and tectonic uplift in southern Norway. The correlation of plateau remnants and their use in reconstructing landscape development is a relatively hazardous undertaking because of the general lack of temporal constraints (Brown et al. 1999; Summerfield 1999). In Norway, as elsewhere, there is no consensus on the age of the surface remnants, which have been varyingly interpreted as being of Jurassic to Paleogene age, nor on their correlation (Gjessing 1967; Torske

Table 1. Parameter values employed

\begin{tabular}{lll}
\hline Symbol & Description & Value \\
\hline$\rho_{\mathrm{c}}$ & Crustal density & $2600 \mathrm{~kg} \mathrm{~m}^{-3}$ \\
$\rho_{\mathrm{a}}$ & Asthenospheric density & $3250 \mathrm{~kg} \mathrm{~m}^{-3}$ \\
$\mathrm{~g}$ & Gravitational acceleration & $9.8 \mathrm{~m} \mathrm{~s}^{-2}$ \\
$D$ & Flexural rigidity of the lithosphere & $8.9 \times 10^{21}$ to $7.2 \times 10^{22} \mathrm{Nm}$ \\
$E$ & Young's modulus & $10^{11} \mathrm{~N} \mathrm{~m}^{-2}$ \\
$\nu$ & Poisson ratio & 0.25 \\
$f$ & Ratio of surface to base loading of lithosphere & 1 \\
$k$ & Thermal conductivity & $0.0006 \mathrm{cal}^{2}\left(\mathrm{~cm} \mathrm{~s} \mathrm{C}^{\circ}\right)^{-1}$ \\
$\alpha$ & Thermal diffusivity & $0.01 \mathrm{~cm}^{2} \mathrm{~s}^{-1}$ \\
$L$ & Lithospheric thickness after thinning & $80-110 \mathrm{~km}$ \\
\hline
\end{tabular}



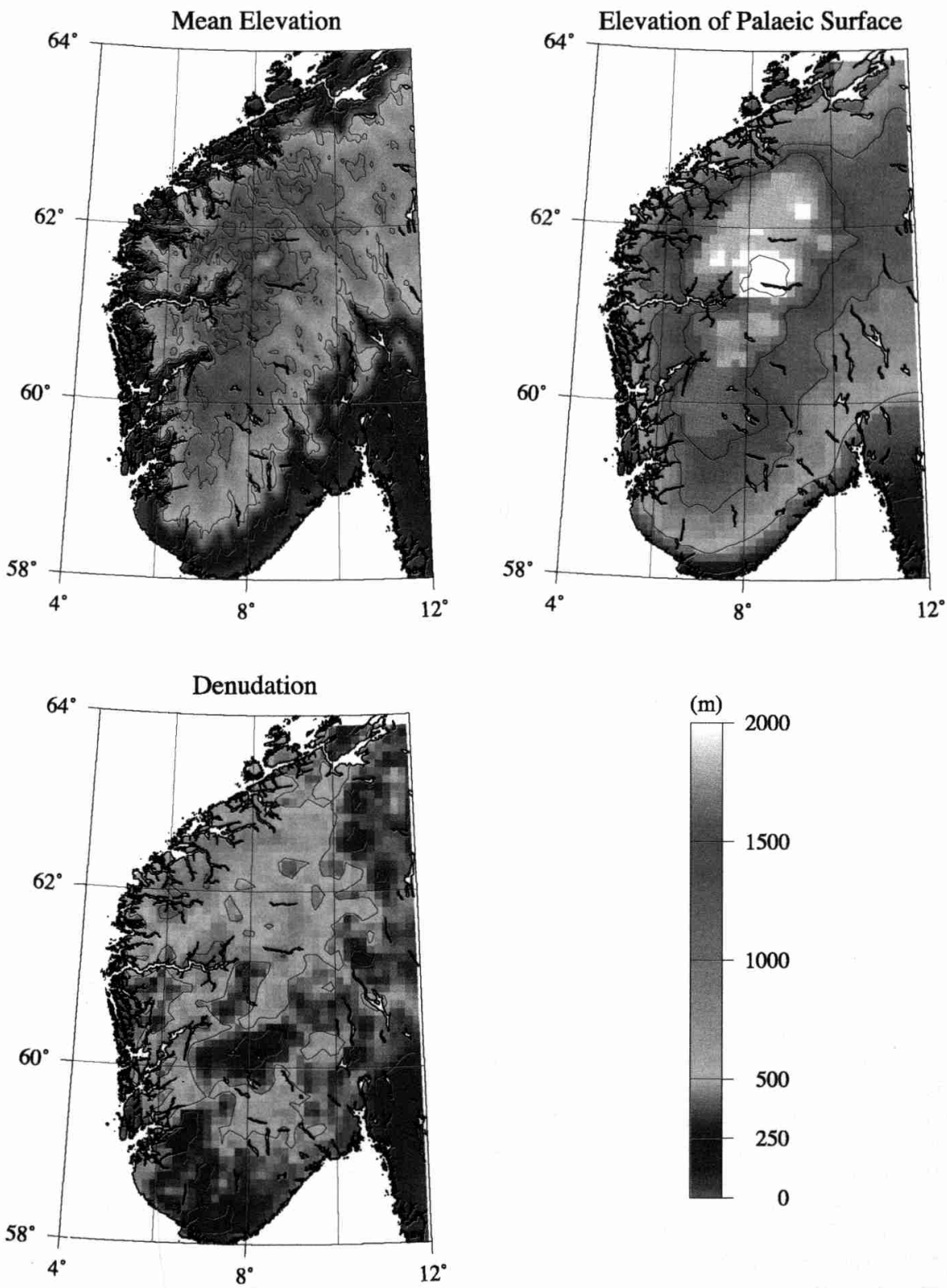

Fig. 3. Maps of mean elevation of southern Norway (from ETOPO-5 global topography data), elevation of the Palaeic surface (after Riis \& Fjeldskaar 1992) and amount of erosion, calculated by subtracting mean elevation from the elevation of the Palaeic surface.

1972; Peulvast 1985; Doré 1992a; Riis \& Fjeldskaar 1992; Riis 1996).

We follow the most recent correlation of Riis \& Fjeldskaar (1992) and Riis (1996), who suggested the Palaeic surface to be of Paleogene age because (1) our fission-track data suggest that samples from close to the Palaeic surface in the Hardangervidda area reached surface temperatures in Paleogene times (Rohrman et al. 1995 ) and (2) the elevation of the Palaeic surface in the Jotunheimen area is consistent with the amount of Neogene denudation recorded by 


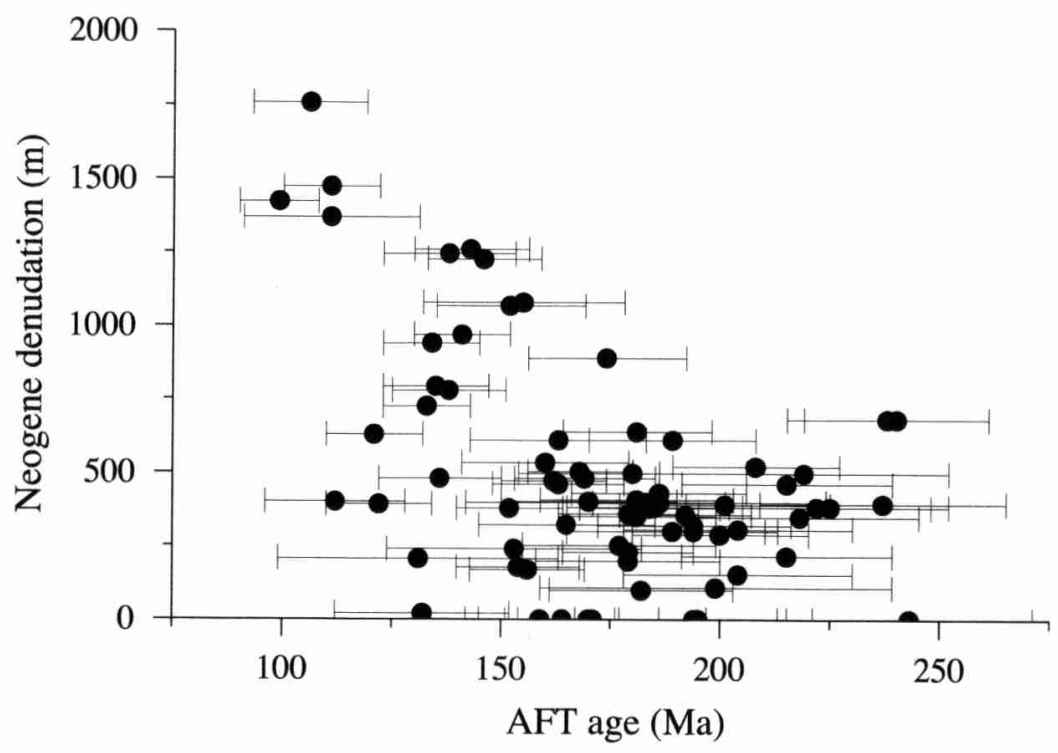

Fig. 4. Correlation of amount of Neogene denudation, calculated by subtracting present-day topography from elevation of Palaeic surface (see Fig. 3) with apatite fission-track ages (from Rohrman et al. 1994, 1995). Neogene denudation for fission-track samples is corrected for sample elevation with respect to mean elevation of the $5^{\prime}$ resolution topographic grid.

fission-track thermochronology of samples from close to sea level $(2.0 \pm 0.5 \mathrm{~km}$; van der Beek 1995).

Figure 3 shows the present-day elevation of southern Norway as well as the elevation of the Palaeic surface. The latter was digitized from the map of Riis \& Fjeldskaar (1992) and interpolated using a continuous curvature algorithm (Smith \& Wessel 1990). The amount of denudation since the formation of the surface (i.e. since the end of Paleogene time) can be calculated by subtracting the present-day elevation $H_{0}$ from the elevation of the Palaeic surface. The result shows a mean amount of denudation of c. $400 \mathrm{~m}$, with maxima of $\geq 1000 \mathrm{~m}$ in the inner fjords and along the northwestern coast. The pattern of denudation that is calculated in this manner is largely consistent with the pattern deduced from fissiontrack thermochronology. Figure 4 shows the correlation between the amount of denudation calculated using this approach and the AFT ages from Rohrman et al. (1995). Although the fission-track ages are mixed ages, with minima around $100 \mathrm{Ma}$, a clear trend emerges with samples with the youngest fission-track ages encountered in the regions of maximum Neogene denudation.

Late Paleocene and early Eocene marine diatoms are encountered on planation surfaces in Sweden and Finland (Fenner 1988), which may be correlated with the Palaeic surface in
Norway. On the basis of this observation, Riis (1996) suggested that the surface was at or near sea level in early Cenozoic time. This assertion is consistent with the offshore sedimentation data (Jordt et al. 1995), which suggest very low sediment input from Fennoscandia before late Oligocene time. We therefore assume that the Palaeic surface can be used as a marker not only of Neogene denudation, but also of uplift.

If we suppose $H_{\mathrm{i}}=0$ in equation (1), then the present-day elevation of the Palaeic surface represents $H_{0}+\Delta E=u_{\mathrm{T}}+I$. In the case of local isostasy $(D=0)$, the amount of isostatic rebound reduces to $I=\Delta E \rho_{\mathrm{c}} / \rho_{\mathrm{a}}(c .0 .8 \Delta E$ for the values in Table 1) and can be calculated directly from the pattern of denudation (Fig. 3). The tectonic uplift $u_{\mathrm{T}}$ then equals the present-day elevation of the Palaeic surface minus the isostatic uplift $I$. Figure 5 shows calculated amounts of Neogene tectonic uplift and isostatic rebound for the local isostatic case. Tectonic uplift in this case has the same domal pattern as the mean elevation and the elevation of the Palaeic surface, reaching maximum values of c. $1500 \mathrm{~m}$ for the high mountain areas (where Neogene denudation is negligible), whereas isostatic rebound reaches a maximum of c. $750 \mathrm{~m}$ in the inner fjords and on the NW coast. However, because the isostatic response to denudation is generally regional instead of local, the pattern and the amount of tectonic uplift will 


\section{Local Isostasy}

Tectonic Uplift

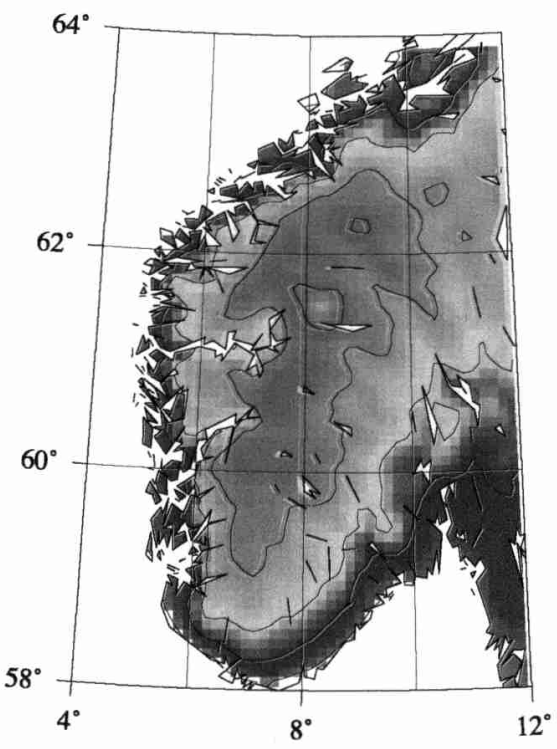

Isostatic Rebound

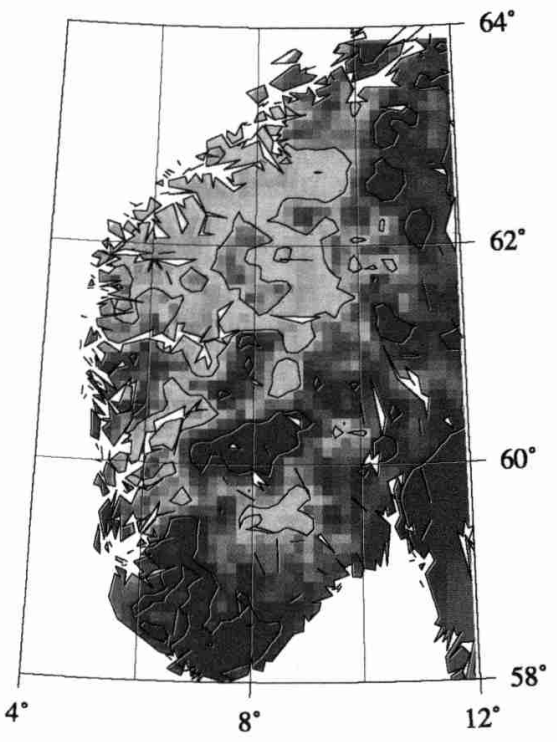

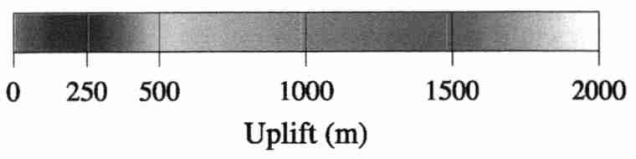

Fig. 5. Calculated tectonic uplift and isostatic rebound for a model of local isostatic response to erosion. In this case isostatic rebound equals 0.8 times the amount of erosion; tectonic uplift was calculated by subtracting this amount from the elevation of the Palaeic surface (see text).

also be a function of the flexural rigidity $D$ of the southern Norwegian lithosphere.

\section{Estimating flexural rigidity}

To make a realistic assessment of the amount of tectonic uplift, the flexural rigidity, or corresponding equivalent elastic thickness $T_{\mathrm{e}}$, must be estimated. Flexural rigidity may be readily estimated by an analysis of the coherence of topography and Bouguer gravity anomalies. Gravity and topography will be coherent at long wavelengths but not at shorter ones, the wavelength at which coherence breaks down being dependent on $D$. The observed coherence $\gamma_{0}^{2}$ is defined as (Forsyth 1985)

$$
\gamma_{0}^{2}=\frac{C_{(\bar{k})}^{2}}{E_{0(\bar{k})} E_{1(\bar{k})}}
$$

where $E_{0(k)}$ is the average power of topography for a discrete wavenumber, $E_{1(k)}$ is the average power of gravity for that wavenumber, $C_{(k)}$ is the cross-spectral power of gravity and topography and the overbar indicates averaging over a wavenumber band. For a mechanically anisotropic lithosphere a similar concept can be used (Simons et al. 2000), but in this analysis we assume isotropy. The theoretical coherence for a plate loaded both at its surface and base is given by (Forsyth 1985)

$$
\gamma^{2}=\frac{\left\langle H_{\mathrm{T}} W_{\mathrm{T}}\right\rangle\left\langle H_{\mathrm{B}} W_{\mathrm{B}}\right\rangle}{\left\langle H_{T}^{2}+H_{B}^{2}\right\rangle\left\langle W_{T}^{2}+W_{B}^{2}\right\rangle}
$$

where $H_{\mathrm{T}}$ is the amplitude of surface deflection as a result of surface loading, $W_{\mathrm{T}}$ is the amplitude of deflection of the base of the plate (i.e. the Moho) as a result of surface loading, $H_{\mathrm{B}}$ the amplitude of surface deflection resulting from loading at the base of the plate and $W_{\mathrm{B}}$ the amplitude of Moho deflection resulting from base loading. $H_{\mathrm{T}}, H_{\mathrm{B}}, W_{\mathrm{T}}$ and $W_{\mathrm{B}}$ depend on the wavenumber $k$ and flexural rigidity $D$ 
via

$$
\begin{gathered}
H_{\mathrm{B}(\mathrm{k})}=f \rho_{\mathrm{c}} H_{\mathrm{T}(\mathrm{k})} / \psi \Delta \rho \\
W_{\mathrm{T}(\mathrm{k})}=-\rho_{\mathrm{c}} H_{\mathrm{T}(\mathrm{k})} / \psi \Delta \rho \\
W_{\mathrm{B}(\mathrm{k})}=-\rho_{\mathrm{c}} H_{\mathrm{B}(\mathrm{k})} \phi / \Delta \rho
\end{gathered}
$$

with $f$ the ratio of surface to base loading; $\Delta \rho=\left(\rho_{\mathrm{a}}-\rho_{\mathrm{c}}\right) ; \quad \phi=1+\left(D k^{4} / \rho_{\mathrm{c}} \mathrm{g}\right)$ and $\psi=$ $1+\left(D k^{4} / \Delta \rho \mathbf{g}\right)$. The flexural rigidity $D$ is related to the equivalent elastic thickness $T_{\mathrm{e}}$ by

$$
D=\frac{E T_{\mathrm{e}}^{3}}{12\left(1-\nu^{2}\right)}
$$

where $E$ is Young's modulus and $\nu$ is the Poisson ratio (see Table 1).

The gravity data we used for this analysis are from the Sveriges Geologiske Undersökelse 1985; Fig. 1) and topography from the ETOPO5 database. Gravity and topography data were projected onto a $500 \mathrm{~km} \times 720 \mathrm{~km}$ UTM grid. Data were clipped in the deep offshore areas and tapered towards the mean value along the sides of the grid, before being transformed into the wavenumber domain using a fast Fourier transform algorithm (see van der Beek 1995).

Results of the coherence analysis are shown in Fig. 6. Although a best-fitting $f$ and $T_{\mathrm{e}}$ can be estimated independently from the data using a least-squares criterion (Forsyth 1985), we feel that this may put too much emphasis on a best-fitting number for the present data quality. Visual inspection indicates a best-fit $T_{\mathrm{e}}$ between 10 and $20 \mathrm{~km}\left(D=8.9 \times 10^{21}\right.$ to $7.1 \times 10^{22} \mathrm{Nm}$ ), assuming $f=1$. This value is at the low end of estimates of flexural rigidity for Fennoscandia from glacial rebound studies, which constrain $T_{\mathrm{e}}$ to be $\leq 50 \mathrm{~km}$ (Fjeldskaar

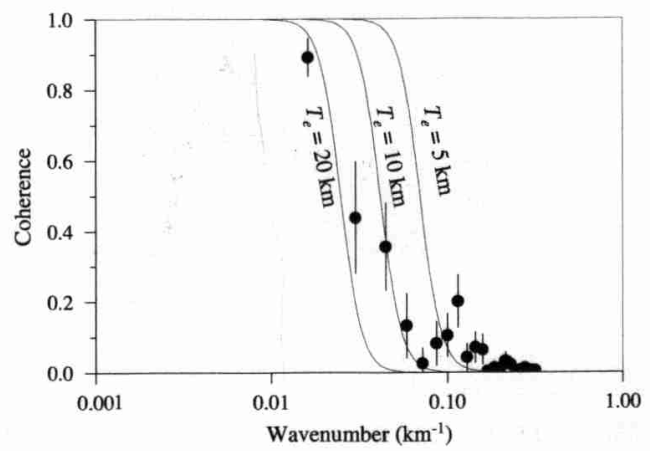

Fig. 6. Results of coherence analysis for southern Norway. Dots indicate observed coherence for average wavenumber bands, bars denote $1 \sigma$ errors. Continuous lines are the various equivalent elastic thicknesses $T_{\mathrm{e}}$.
\& Cathles 1991). It is, however, consistent with regional $T_{\mathrm{e}}$ estimates from the postglacial tilt of palaeoshorelines (Fjeldskaar 1997), which suggested $T_{\mathrm{e}} \leq 20 \mathrm{~km}$, as well as with an independent coherence study by Poudjom Djomani et al. (1999), who found $8 \leq T_{\mathrm{e}} \leq 18 \mathrm{~km}$ for southern Norway.

We have calculated the isostatic response to denudation adopting constant $T_{\mathrm{e}}$ values of 10 and $20 \mathrm{~km}$, using equation (2). The predicted isostatic rebound has a much smoother pattern than the local isostatic case, reaching a maximum of c. $700 \mathrm{~m}$ near the NW coastline (Fig. 7). The magnitude of isostatic rebound is, however, not much smaller than for the local isostatic case, as the inferred flexural rigidity is not very large. Resulting tectonic uplift patterns are also shown in Fig. 7; the models incorporating flexural rigidity show a similar dome-shaped uplift pattern as the local isostatic case. Uplift is centred on the regions of highest present-day elevation, reaching a maximum of $c .1500 \mathrm{~m}$. This surprisingly high value is relatively insensitive to the adopted flexural rigidity because, as $D$ increases, the amount of isostatic rebound decreases but also spreads more toward the regions of highest present-day elevation and contributes to the uplift of these regions. The critical assumption in this analysis is that the Palaeic surface was at sea level before Neogene uplift; if it was at some initial elevation $H_{\mathrm{i}}$ the inferred Neogene uplift will be overestimated by the same amount (see equation (1)).

\section{Southern Norway: mechanisms of uplift}

The relatively low flexural rigidity of the lithosphere $\left(c .10^{22} \mathrm{~N} \mathrm{~m}\right)$ and high tectonic uplift strongly suggest an endogenous cause for the uplift. This leaves us with essentially two possible solutions: intraplate compression and dynamic mantle upwelling. Intraplate processes require positive gravity anomalies below the dome regions, in contrast to the observations. Furthermore, intraplate compression cannot generate the amount of uplift required, as it is an order of magnitude too low (van der Beek 1995).

Mantle upwelling has been proposed by various workers for the North Atlantic margins (e.g. Vågnes \& Amundsen 1993; Stuevold \& Eldholm 1996; Rohrman \& van der Beek 1996). The upwelling model seems plausible for Spitsbergen, where high heat flow (c. $130 \mathrm{~mW} \mathrm{~m}^{-2}$ ) prevails and mantle xenoliths are present in Quaternary alkali basalts. This model seems less obvious for southern Norway, where low surface heat flow (c. $40 \mathrm{~mW} \mathrm{~m}^{-2}$ ) 


$$
T_{e}=10 \mathrm{~km}
$$

Tectonic Uplift

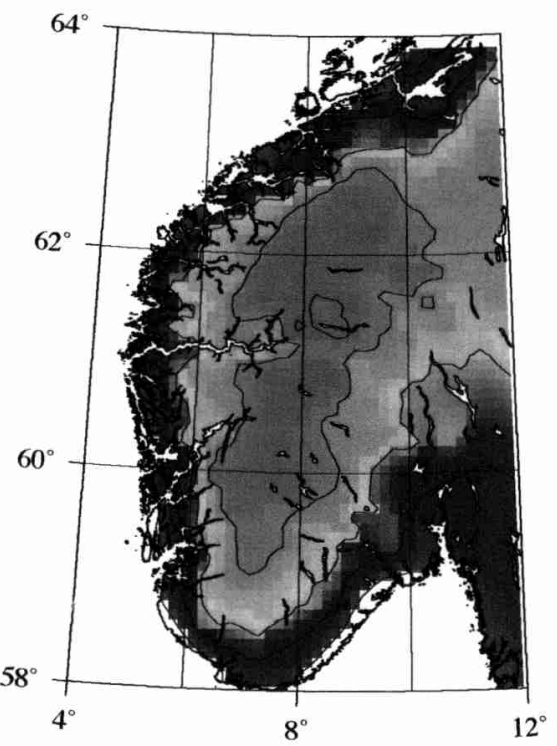

Isostatic Rebound

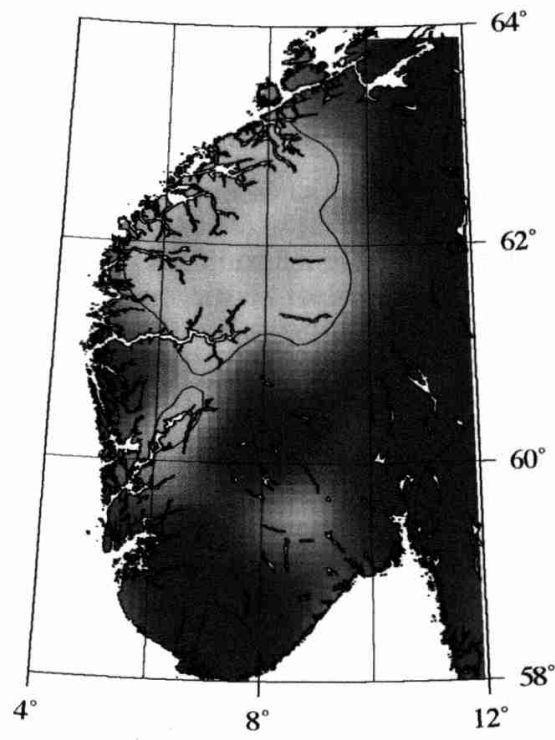

$$
T_{e}=20 \mathrm{~km}
$$

Tectonic Uplift

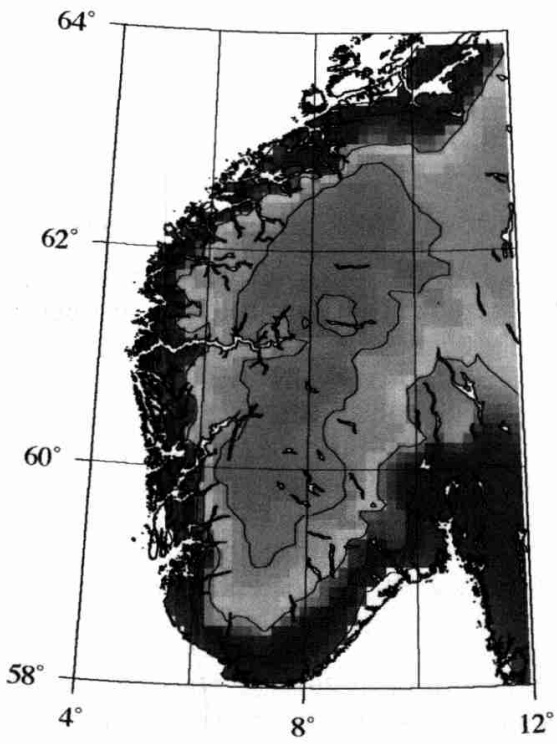

Isostatic Rebound

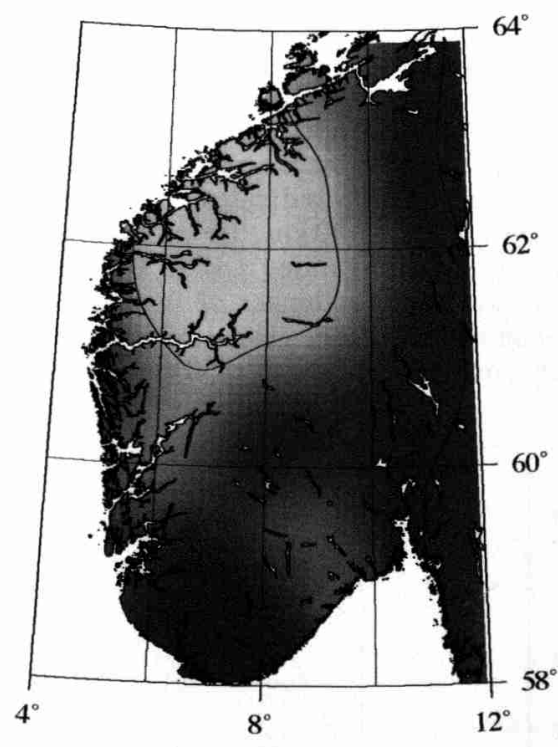

$62^{\circ}$ $58^{\circ}$

$12^{\circ} \quad 4^{\circ}$

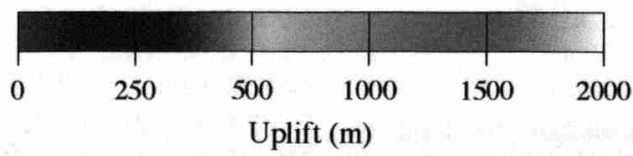

Fig. 7. Calculated tectonic uplift and isostatic rebound for a model of regional isostatic response to denudation and different flexural rigidities, corresponding to $T_{\mathrm{e}}=10 \mathrm{~km}\left(D=8.9 \times 10^{21} \mathrm{Nm}\right.$; top $)$ and $T_{\mathrm{e}}=20 \mathrm{~km}$ $\left(D=7.1 \times 10^{22} \mathrm{~N} \mathrm{~m}\right.$; bottom). (See text for discussion.) 
(Cermak 1979; Balling 1995) and lack of volcanism are not readily consistent with mantle upwelling. However, a recent study by Goes et al. (2000) proposed high sub-Moho temperatures in excess of $1000^{\circ} \mathrm{C}$ based on P- and S-wave tomography below southern Norway (Fig. 8). These temperatures are similar to those in regions such as the Massif Central (Sobolev et al. 1996), where a mantle plume seems evident. If these temperature estimates are correct, the discrepancy between surface heat flow and elevated temperatures at depth can be explained by a time lag between equilibration of high lithospheric heat flow and surface heat flow (McGuire \& Bohannon 1989). Assuming conductive heat loss, the change in surface heat flow $\Delta q_{\mathrm{o}}$ is related to a change in temperature at the base of the thinned lithosphere $\Delta T_{1}$, the thickness of the lithosphere after thinning $L$, and the diffusion time $t$, according to

$\Delta q_{\mathrm{o}}=\frac{k \Delta T_{1}}{L}\left\{1+2 \sum_{n=1}^{\infty} \cos (n \pi) \exp \left[\frac{-n^{2} \pi^{2} \alpha t}{L^{2}}\right]\right\}$

where $k$ is thermal conductivity and $\alpha$ the thermal diffusivity (Table 1 ). For $L$ between 110 and $80 \mathrm{~km}$ and $\Delta T_{1}$ from $400{ }^{\circ} \mathrm{C}$ to $500{ }^{\circ} \mathrm{C}$, it takes around $60 \mathrm{Ma}$ to observe a $c .10 \mathrm{~mW} \mathrm{~m}^{-2}$ heatflow change for southern Norway.

Upwelling material is most probably associated with advection, therefore we can use a $10 \mathrm{~mW} \mathrm{~m}^{-2}$ heat-flow change as a conservative estimate. As no regional heat-flow anomalies are observed in the southern Norwegian data, we assume that any dynamic mantle upwelling must be younger than $60 \mathrm{Ma}$. Along with the evidence of reduced $\mathrm{P}$ and $\mathrm{S}$ waves below southern Norway (Bannister et al. 1991; see also below), this strongly suggests that the southern Norwegian structural dome was generated by active mantle upwelling or diapirism in Neogene time.

\section{Seismic tomography of the North Atlantic}

One of the major advances in our understanding of the Earth has been the advent and subsequent development of seismic tomography, a class of imaging that now provides increasingly detailed 3D maps of seismic velocity variations that can be related to thermal and chemical variations in the mantle. Although it has proven relatively easy to image downwellings (i.e. subducting slabs), it seems much more difficult to image mantle upwellings (e.g. Grand et al. 1997). This is because upwellings are likely to occur in aseismic regions and are not as well sampled by seismic data, especially in the shallow mantle. Furthermore, use of first arrivals of seismic waves causes a natural bias toward fast anomalies, because annealing of wavefronts creates a tendency to underestimate slow anomaly amplitudes. Another important issue is that resolution depends on data coverage, which is uneven owing to the sparse distribution of sources (i.e. earthquakes) and receivers (i.e. seismological stations) and the 3D geometry of the ray paths along which the seismic waves propagate. Mantle structure has remained unresolved beneath large regions of the North Atlantic because of absence of recording stations and low levels of seismic activity.

With this in mind, we present P-wave velocity maps of the North Atlantic at various depths (Fig. 9), which provide a snapshot of the mantle

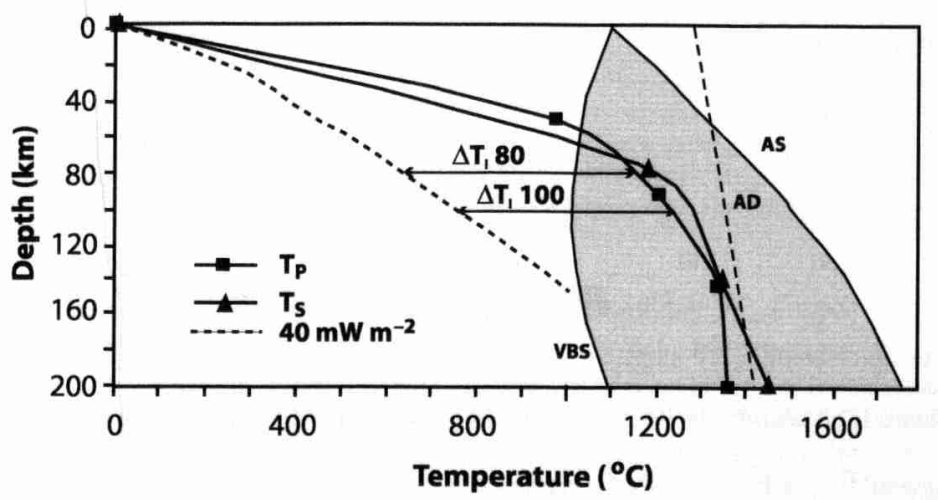

Fig. 8. Temperature-depth plot of three geotherms below southern Norway. The $40 \mathrm{~mW} \mathrm{~m}^{-2}$ geotherm (broken line) is based on surface heat-flow data. $T_{\mathrm{P}}$ and $T_{\mathrm{S}}$ are geotherms derived from inversion of $\mathrm{P}$-wave and $\mathrm{S}$-wave seismic velocities, respectively (Goes et al. 2000; Goes pers. comm.). The relative convergence of $T_{\mathrm{P}}$ and $T_{\mathrm{S}}$ should be noted. VBS, volatile-bearing peridotite solidus; AS, anhydrous peridotite solidus; AD, adiabat. 

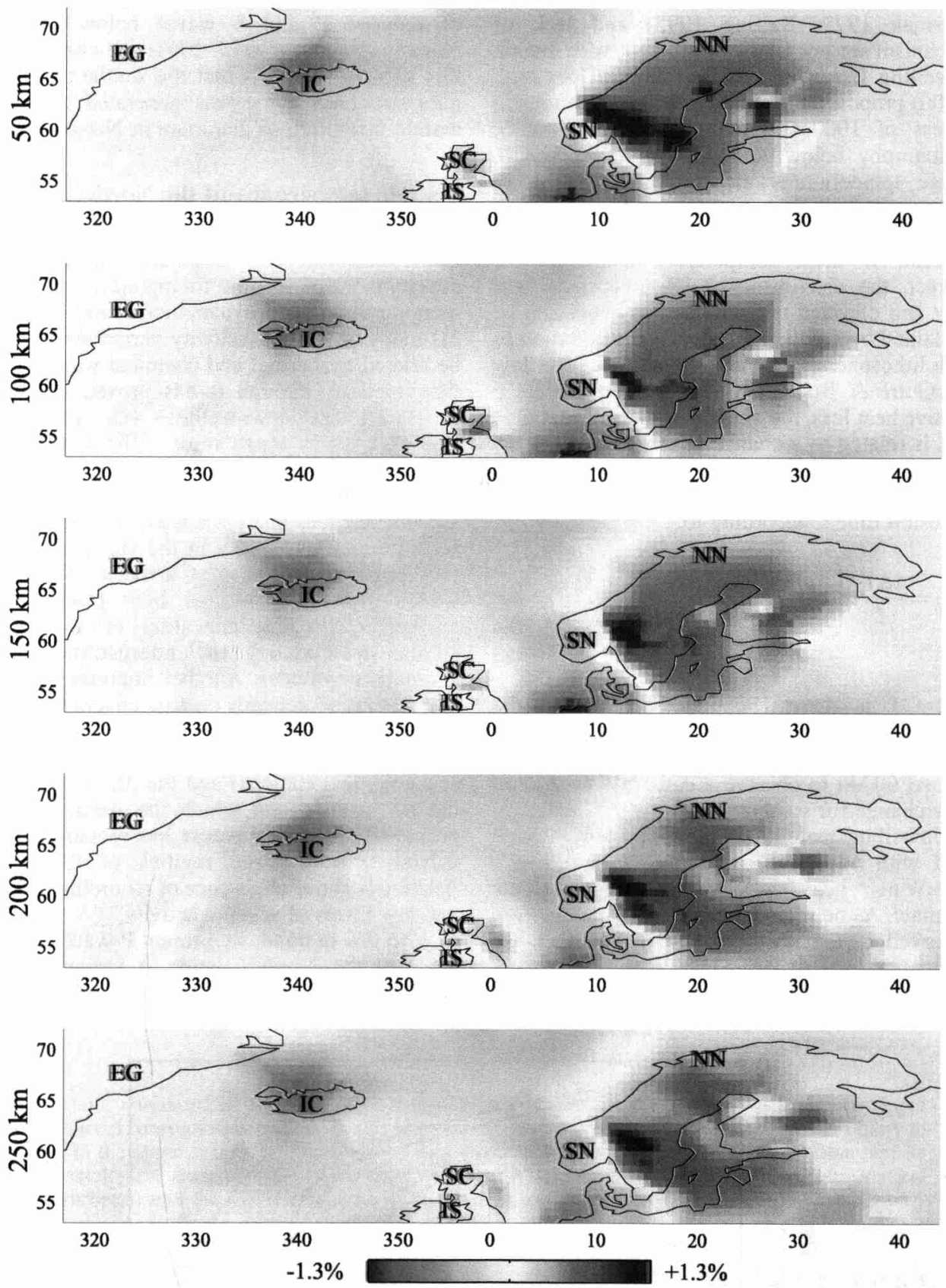

Fig. 9. P-wave seismic tomography maps for the North Atlantic at various depths. For the upper mantle low velocities (red) correspond to high temperatures, whereas high velocities (blue) correspond to low temperatures. EG, East Greenland; IC, Iceland; SN, southern Norway; NN, northern Norway; IS, Irish Sea; SC, Scotland.

as it is today. The image (Fig. 9) depicts P-wave velocity maps through the global model of Kárason \& van der Hilst (2000) for the North Atlantic region. Figure 10 shows a resol- ution test for the velocity map at $150 \mathrm{~km}$, using a chequerboard model. Resolution is rather poor below East Greenland (EG) and most of the North Atlantic Ocean. A better 

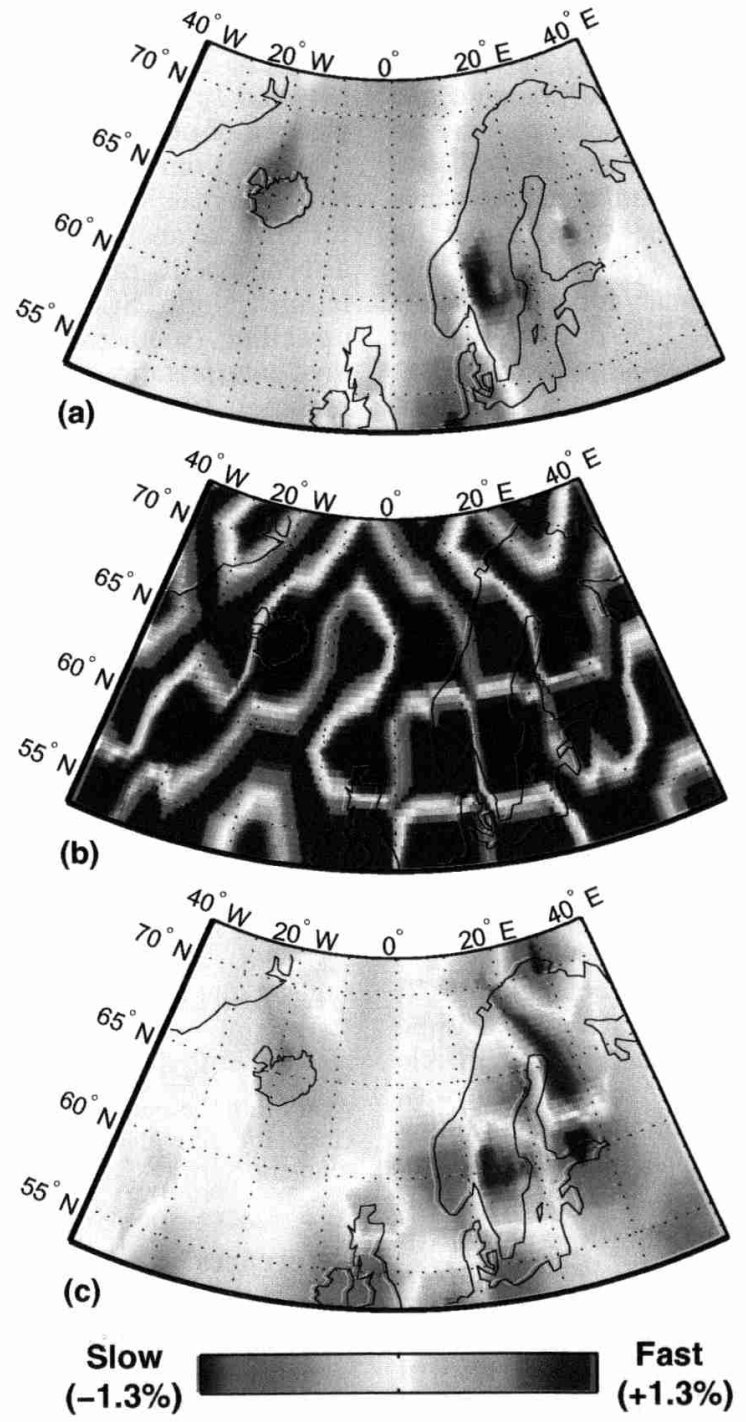

Fig. 10. (a) Lateral variations of $\mathrm{P}$-wave speed at $150 \mathrm{~km}$ depth beneath the northern Atlantic. (b) Input 'chequerboard' model for resolution test. (c) Result of 'chequerboard' resolution test; as expected, our ability to image structure in the upper mantle beneath the oceanic regions is very poor owing to absence of earthquake sources and seismological stations, but beneath southern Norway the lateral resolution is reasonable. Vertical resolution is poor because of the small incidence angles of the seismic waves used for imaging in this region.

defined low-velocity anomaly is detected below Iceland (IC). This anomaly extends from near the surface to $c .400 \mathrm{~km}$, but a deeper structure could have been overlooked owing to insufficient data coverage (e.g. Keller et al. 2000). Below southern Norway $(\mathrm{SN})$ a low-velocity anomaly is observed that extends from $>50 \mathrm{~km}$ depth to $>250 \mathrm{~km}$. The vertical resolution is poor in this part of the model, but the slow anomaly agrees well with previous $\mathrm{P}$ - and S-wave tomographic studies (Bannister et al. 1991; Zielhuis \& Nolet 1994a, 1994b; Marquering \& Snieder 1996; Bijwaard et al. 1998). Although this is not likely to be well resolved, the model suggests that a thin high-velocity layer overlies a low-velocity anomaly below southern Norway, which is consistent with our estimates of $T_{\mathrm{e}}$ and suggests a thinned and relatively weak lithosphere. Farther eastward we encounter the Baltic shield, evident as a thick $(>250 \mathrm{~km})$ high-velocity area. The 
change from a low-velocity zone in the upper mantle of southern Norway (SN) to the high velocities of the Baltic shield is dramatic and suggests some fundamental process that has so far been neglected in our current view of plate tectonics. We remark that similar features have been observed in southeastern Australia (Zielhuis \& van der Hilst 1996). Here, a lowvelocity upper-mantle anomaly is depicted below the mountains (up to $2230 \mathrm{~m}$ ) of Eastern Australia, whereas the low-altitude $(<200 \mathrm{~m})$ shield towards the west shows higher velocities.

Regional tomographic studies (Bannister et al. 1991) indicate a low-velocity anomaly below northern Norway $(\mathrm{NN})$, but in our global model resolution is too low to infer any details for this region. Similar resolution problems are observed below the British Isles, where faint low-velocity anomalies are present below the Irish Sea (IS) at c. $200 \mathrm{~km}$ depth. Low velocities below the Irish Sea were also observed in previous models (Marquering \& Snieder 1996; Bijwaard et al. 1998). Scotland (SC) also suffers from the aforementioned resolution problems, but generally suggests higher velocities.

\section{Discussion}

Our results from integrating geological, AFT, geomorphological, Bouguer gravity and seismic tomography data strongly suggest that mantle upwelling is present below southern Norway. Furthermore, it seems evident that this upwelling was most active in Neogene time and directly responsible for generating most of the presentday topography. Whether other areas experienced similar upwellings is still uncertain, mainly because of lack of sufficient data. However, there are strong indications that similar mechanisms generated the domal topography of Spitsbergen, northern Norway and the East Greenland coast (Rohrman \& van der Beek 1996). There are also some structural differences among the domes. Whereas Spitsbergen records Neogene volcanism, southern Norway is completely devoid of any Cenozoic magmatic activity. This is probably simply constrained by the amount of active lithosphere thinning by the upwelling. Spitsbergen's lithospheric thickness is estimated to be $c .50 \mathrm{~km}$ (Vågnes \& Amundsen 1993), whereas the south Norwegian lithosphere is much thicker, probably $c$. $80-100 \mathrm{~km}$. The Norwegian dome thus possibly represents an early stage of upwelling. Additionally, the P- and S-wave temperatures of Goes et al. (2000) for Europe suggest that divergence of $T_{\mathrm{P}}(\mathrm{P}$-wave temperature) and $T_{\mathrm{S}}$ (S-wave temperature) at depths $<100 \mathrm{~km}$ could indicate the presence of melt, as shown for the Massif Central area. Southern Norway shows relative convergence between $T_{\mathrm{P}}$ and $T_{\mathrm{S}}$ (Fig. 8), possibly suggesting absence of melt and therefore no volcanism.

Apart from explaining observed uplift patterns, the mantle upwellings also offer a solution for offshore anomalous basin subsidence, where asthenospheric material flows from below the basins (North Sea, Møre Basin) toward the upwelling (southern Norway). Furthermore, in this interpretation the timing of upwelling becomes less of an issue, as the available evidence suggests that boundary conditions are generated by rifting over an anomalously hot asthenosphere. Subsequent uplift pulses might be inferred by changes in upwelling flux (Rohrman \& van der Beek 1996; White \& Lovell 1997).

Some concerns remain; mantle upwellings seem to follow a distinct sequence of events, starting with surface uplift, followed by basaltic volcanism and finally thermal subsidence. Alternatively, our results might suggest that not all upwellings cause surface volcanism, as upwelling temperature and velocity could be too low. Another question is the relationship between plate movement and upwelling. Traditional theory suggests that upwellings remain stationary with respect to each other, but our results suggest that this might not always be the case.

We thank Shell UK Exploration \& Production for sponsoring the color figures in this article and Saski Goes for providing the temperature data below southern Norway

\section{References}

Аввотt, L.D., Silver, E.A., Anderson, R.S. \& 7 OTHERS 1997. Measurement of tectonic surface uplift rate in a young collisional orogen. Nature, 385, 501-507.

BALling, N. 1980. The land uplift in Fennoscandia, gravity field anomalies and isostasy. In: MöRNER, N.A. (ed.) Earth, Rheology, Isostasy and Eustasy. Wiley, Chichester, 297-321.

BALling, N. 1995. Heat flow and thermal structure across the Baltic shield and northern Tornquist zone. Tectonophysics, 245, 13-50.

Bannister, S.C., Ruud, B.O. \& Husebye, E.S. 1991. Tomographic estimates of sub-Moho seismic velocities in Fennoscandia and structural implications. Tectonophysics, 189, 37-53.

BiJWAARD, H., SPAKMAN, W. \& ENGDAhL, E.R. 1998. Closing the gap between regional and global travel time tomography. Journal of Geophysical Research, 103, 30055-30078.

Blythe, A.E. \& KLeINSPEHN, K.L. 1998. Tectonically versus climatically driven Cenozoic exhumation of the Eurasian plate margin, Svalbard: fission track analyses. Tectonics, 17, 621-639. 
Brodie, J. \& White, N. 1995. The link between sedimentary basin inversion and igneous underplating. In: Buchanan, J.G. \& Buchanan, P.G. (eds) Basin Inversion. Geological Society, London, Special Publications, 88, 21-38.

Brown, R.W., Gallagher, K., Gleadow, A.J.W. \& Summerfield, M.A. 1999. Morphotectonic evolution of the South Atlantic margins of Africa and South America. In: Summerfield, M.A. (ed.) Global Tectonics and Geomorphology. Wiley, Chichester, 257-283.

Cermak, V. 1979. Heat flow map of Europe. In: Cermak, V. \& RYBACH, L. (eds) Terrestrial Heatflow in Europe. Springer, Berlin, 3-40.

Cloetingh, S., Gradstein, F.M., Kooi, H., Grant, A.C. \& KAMINSKI, M. 1990. Plate reorganization; a cause of rapid late Neogene subsidence and sedimentation around the North Atlantic. Journal of the Geological Society, London, 147, 495-506.

Cox, K.G. 1993. Continental magmatic underplating. Philosophical Transactions of the Royal Society of London, Series A, 342, 155-166.

Dam, G., Larsen, M. \& Sørensen, J.C. 1998. Sedimentary response to mantle plumes: implications from Paleocene onshore successions West and East Greenland. Geology, 26, 207-210.

DoRÉ, A.G. 1992a. The Base Tertiary surface of southern Norway and the northern North Sea. Norsk Geologisk Tidsskrift, 72, 259-265.

DoRÉ, A.G. 1992b. The structural foundation and evolution of Mesozoic seaways between Europe and the Arctic. Paleogeography, Paleoclimatology, Paleoecology, 87, 441-492.

Doré, A.G., Lundin, E.R., Jensen, L.N., Birkeland, O., Eliassen, P.E. \& Fichler, C. 1999. Principal tectonic events in the evolution of the northwest European margin. In: FLEET, A.J. \& BOLDY, S.A.R. (eds) Petroleum Geology of Northwest Europe: Proceedings of the 5th Conference. Geological Society, London, 41-61.

England, P. \& Molnar, P. 1990. Surface uplift, uplift of rocks, and exhumation of rocks. Geology, 18, $1173-1177$.

Eyles, N. 1996. Passive margin uplift around the North Atlantic and its role in Northern Hemisphere late Cenozoic glaciation. Geology, 24, 103-106.

FENNER, J. 1988. Occurrences of pre-Quaternary diatoms in Scandinavia reconsidered. Meyniana, 40, 133-141.

FJELDSKAAR, W. 1997. Flexural rigidity of Fennoscandia inferred from the post-glacial uplift. Tectonics, 16, 596-608.

FueldskaAR, W. \& Cathles, L. 1991. Rheology of mantle and lithosphere inferred from post-glacial uplift in Fennoscandia. In: SABADINI, R., LAMBECK, K. \& Bossi, E. (eds) Glacial Isostasy, Sea-Level and Mantle Rheology. Kluwer, Dordrecht, 1-19.

FORSYTH, D.W. 1985. Subsurface loading and estimates of the flexural rigidity of continental lithosphere. Journal of Geophysical Research, 90, 12623-12632.

Gilchrist, A.R., Summerfield, M.A. \& CockBurn, H.A.P. 1994. Landscape dissection, isostatic uplift, and the morphologic development of orogens. Geology, 22, 963-966.

Gjessing, J. 1967. Norway's Paleic surface. Norsk Geografisk Tidsskrift, 21, 69-132.

Goes, S., Govers, R. \& VACher, P. 2000. Shallow mantle temperatures under Europe from $\mathrm{P}$ and $\mathrm{S}$ wave tomography. Journal of Geophysical Research, 105, 11153-11169.

GRAND, S.P., VAN DER HILST, R.D. \& WidiYANTORO, S. 1997. Global seismic tomography: a snapshot of convection in the Earth. GSA Today, 7, 1-7.

GreEN, P.F., DudDY, I.R. \& BRAY, R.J. 1997. Variation in thermal history styles around the Irish Sea and adjacent areas: implications for hydrocarbon occurrence and tectonic evolution. In: MEADOws, N.S., Trueblood, S.P., Hardman, M. \& Cowan, G. (eds) Petroleum Geology of the Irish Sea and Adjacent Areas. Geological Society, London, Special Publications, 124, 73-93.

Green, P.F., Duddy, I.R., Bray, R.J. \& Lewis, C.L.E. 1993. Elevated paleotemperatures prior to early Tertiary cooling throughout the UK region. In: Parker, J.R. (ed.) Petroleum Geology of $N W$ Europe: Proceedings of the 4th Conference. Geological Society, London, 1067-1074.

Green, P.F., Thomson, K. \& Hudson, J.D. 2001. Recognition of tectonic events in undeformed regions: contrasting results from the Midland Platform and east Midlands Shelf, Central England. Journal of the Geological Society, London, 158, 59-73.

HENDRIKS, B.W.H. \& ANDriessen, P.A.M. 2002. Pattern and timing of the post-Caledonian exhumation of northern Scandinavia constrained by apatite fission-track thermochronology. In: DORÉ, A.G., Cartwright, J.A., Stoker, M.S., Turner, J.P. \& White, N. (eds) Exhumation of the North Atlantic Margin: Timing, Mechanism and Implications for Petroleum Exploration. Geological Society, London, Special Publications, 196, 117-137.

Holtedahl, H. 1953. On the oblique uplift of some Northern lands. Norsk Geografisk Tidsskrift, 14, $132-139$.

JAPSEN, P. 1997. Regional Neogene exhumation of Britain and the western North Sea. Journal of the Geological Society, London, 154, 239-247.

JAPSEN, P. \& Chalmers, J.A. 2000. Neogene uplift and tectonics around the North Atlantic: overview. Global and Planetary Change, 24, 165-173.

JENSEN, L.N. \& SchmidT, B.J. 1993. Neogene uplift and erosion in the northeastern North Sea; magnitude and consequences for hydrocarbon exploration in the Farsund Basin. In: SPENCER, A.M. (ed.) Generation, Accumulation and Productions of Europe's Hydrocarbons. European Association of Petroleum Geologists Special Publication, 3, 79-88.

JoRdT, H., FALEIDE, J.I., BJøRLyKKe, K. \& IBRAhim, M.T. 1995. Cenozoic sequence stratigraphy in the central and northern North Sea Basin: tectonic development, sediment distribution and provenance areas. Marine and Petroleum Geology, 12, $845-880$. 
Kárason, H. \& van der Hilst, R.D. 2000. Constraints on mantle convection from seismic tomography. In: Richards, M.R., GORDON, R. \& VAN DER HiLsT, R.D. (eds) The History and Dynamics of Global Plate Motion. Geophysical Monograph, American Geophysical Union, 121, 277-288.

Keller, W.R., Anderson, D.L. \& Clayton, R.W. 2000. Resolution of tomographic models of the mantle beneath Iceland. Geophysical Research Letters, 27, 3993-3996.

Lewis, C.L.E., Carter, A. \& Hurford, A.J. 1992. Low temperature effects of the Skye Tertiary intrusions on Mesozoic sediments in the Sea of Hebrides basin. In: PARnell, J. (ed.) Basins on the North Atlantic Seaboard: Petroleum Geology, Sedimentology, and Basin Evolution. Geological Society, London, Special Publications, 62, 175-188.

Marquering, H. \& Snieder, R. 1996. Shear wave velocity structure beneath Europe, the northeastern Atlantic and western Asia from waveform inversions including surface-wave mode coupling. Geophysical Journal International, 124, 283-304.

Martinsen, O.J., Bøen, F., Charnock, M.A., Mangerud, G. \& Nøttredt, A. 1999. Cenozoic development of the Norwegian margin $60-64^{\circ} \mathrm{N}$ : sequences and sedimentary response to variable basin physiography and tectonic setting. In: Fleet, A.J. \& Boldy, S.A.R. (eds) Petroleum Geology of Northwest Europe: Proceedings of the 5th Conference. Geological Society, London, 293-304.

McGuire, A.V. \& Bohannon, R.G. 1989. Timing of mantle upwelling: evidence for a passive origin for the Red Sea rift. Journal of Geophysical Research, 94, 1677-1682.

Mokhtari, M. \& Pegrum, R.M. 1992. Structure and evolution of the Lofoten continental margin, offshore Norway. Norsk Geologisk Tidsskrift, 72, 339-355.

Nøttvedt, A., Livbjerg, F., Midbøe, P.S. \& RASMUSSEN, E. 1992. Hydrocarbon potential of the Central Spitsbergen basin. In: VoRren, T.O., Bergsaker, E., Dahl-Stamnes, Ø.A., Holter, E., Johansen, B., Lie, E. \& Lund, T.B. (eds) Arctic Geology and Petroleum Potential. Norwegian Petroleum Society Special Publication, 2, 333-361.

Peulvast, J.-P. 1985. Post-orogenic morphotectonic evolution of the Scandinavian Caledonides during the Mesozoic and Cenozoic. In: GeE, D.G. \& STURT, B.A. (eds) The Caledonide OrogenScandinavia and Related Areas. Wiley, Chichester, 979-995.

PoudJom dJomani, Y.H., FaIRHEAD, J.D. \& GRIFFIN, W.L. 1999. The flexural rigidity of Fennoscandia: reflection of the tectonothermal age of the lithospheric mantle. Earth and Planetary Science Letters, 174, 139-154.

RIIS, F. 1996. Quantification of Cenozoic vertical movements of Scandinavia by correlation of morphological surfaces with offshore data. Global and Planetary Change, 12, 331-358.
RIIS, F. \& FJELDSKAAR, W. 1992. On the magnitude of the Late Tertiary and Quaternary erosion and its significance for the uplift of Scandinavia and the Barents Sea. In: LARSEN, R.M., BREKKE, H., LARSEN, B.T. \& TAlleraAs, E. (eds) Structural and Tectonic Modelling and its Application to Petroleum Geology. Norwegian Petroleum Society Special Publication, 1, 163-185.

Rohrman, M. \& van der Beek, P. 1996. Cenozoic postrift domal uplift of North Atlantic margins: an asthenospheric diapirism model. Geology, 24, 901-904.

Rohrman, M., VAN DER BEEK, P. \& ANDRIESSEN, P.A.M. 1994. Syn-rift thermal structure and postrift evolution of the Oslo Rift (SE Norway): new constraints from fission track thermochronology. Earth and Planetary Science Letters, 127, 39-54.

Rohrman, M., VAn Der BeEK, P.A., ANDriessen, P.A.M. \& Cloetingh, S. 1995. Meso-Cenozoic morphotectonic evolution of Southern Norway: Neogene domal uplift inferred from apatite fission track thermochronology. Tectonics, 14, 704-718.

Rundberg, Y. \& Smalley, P.C. 1989. High-resolution dating of Cenozoic sediments from the northern North Sea using ${ }^{87} \mathrm{Sr} /{ }^{86} \mathrm{Sr}$ stratigraphy. AAPG Bulletin, 73, 298-308.

Simons, F.J., Zuber, M.T. \& Korenaga, J. 2000. Isostatic response of the Australian lithosphere: estimation of effective elastic thickness and anisotropy using multitaper spectral analysis. Journal of Geophysical Research, 105, 19163-19184.

SMALl, E. \& ANDERSON, R.S. 1998. Pleistocene relief production in Laramide mountain ranges, western Unites States. Geology, 26, 123-126.

Smith, W.H.F. \& WESSEL, P. 1990. Gridding with continuous curvature splines in tension. Geophysics, 55, 293-305.

Sobolev, S.V., Zeyen, H., Stoll, G., Werling, F., AltherR, R. \& Fuchs, K. 1996. Upper mantle temperature from teleseismic tomography of French Massif Central including effects of composition, mineral reactions, anharmonicity, anelasticity and partial melt. Earth and Planetary Science Letters, 139, 147-163.

Stuevold, L.M. \& Eldholm, O. 1996. Cenozoic uplift of Fennoscandia inferred from a study of the mid-Norwegian margin. Global and Planetary Change, 12, 359-386.

SummerField, M.A. 1999. Geomorphology and global tectonics: introduction. In: SUMMERFIELD, M.A. (ed.) Geomorphology and Global Tectonics. Wiley, Chichester, 3-11.

Sveriges Geologiske Undersökelse, 1985. Scandinavian Caledonides gravity anomaly map. In: GEE, D.G. \& SturT, B.A. (eds) The Caledonide Orogen-Scandinavia and Related Areas. Wiley, Chichester.

Theilen, F. \& Meissner, R. 1979. A comparison of crustal and upper mantle features in Fennoscandia and the Rhenish Shield, two areas of recent uplift. Tectonophysics, 61, 227-242. 
ToRske, T. 1972. Tertiary oblique uplift of western Fennoscandia; crustal warping in connection with rifting and break-up of the Laurasian continent. Norges Geologiske Undersøkelse, 273, 43-48.

VÅgnes, E. \& AMUndsen, H.E.F. 1993. Late Cenozoic uplift and volcanism on Spitsbergen: caused by mantle convection? Geology, 21, $251-254$.

VAN DER BEEK, P.A. 1995. Tectonic evolution of continental rifts: inferences from numerical modelling and fission track thermochronology. $\mathrm{PhD}$ thesis, Vrije Universiteit Amsterdam.

VAN DER BeEk, P.A. \& Rohrman, M. 1997. Passive margin uplift around the North Atlantic region and its role in Northern Hemisphere late Cenozoic glaciation: Comment. Geology, 25, 282.

VAN DER BEeK, P.A., Cloetingh, S. \& ANDRIEsSEN, P.A.M. 1994. Mechanisms of extensional basin formation and vertical motions at rift flanks: constraints from tectonic modelling and fission-track thermochronology. Earth and Planetary Science Letters, 121, 417-433.

White, N. \& Lovell, B. 1997. Measuring the pulse of a plume with the sedimentary record. Nature, $\mathbf{3 8 7}$, $888-891$.

Zielhuis, A. \& Nolet, G. 1994a. Deep seismic expression of an ancient plate boundary in Europe. Science, 265, 79-81.

Zielhuis, A. \& Nolet, G. 1994b. Shear-wave velocity variations in the upper mantle beneath central Europe. Geophysical Journal International, 117, 695-715.

Zielhuis, A. \& VAN DER Hilst, R.D. 1996. Mantle structure beneath the eastern Australian region from partitioned waveform inversion. Geophysical Journal International, 127, 1-16. 